Olga N. Buchinskaya Ural Federal University named after the first President of Russia Boris N. Yeltsin, Ekaterinburg, Russia

Evgeniy P. Dyatel Ural Federal University named after the first President of Russia Boris N. Yeltsin, Ural State University of Economics, Ekaterinburg, Russia

\title{
Influence of high-technology exports and foreign charges for the use of intellectual property on economic growth
}

\begin{abstract}
The study aims to identify the interrelation between high-technology exports and the growth of national economies of European countries. Methodologically, the authors rely on the conceptual principles of the theory of economic inequality developed by Erik Reinert and the ideology of export-oriented growth. The main research hypothesis rests on the assumption that the possibility of participating in the export of high-tech goods and intellectual property is essential for the country to achieve a high economic level. Therefore, for countries with a lower level of economic development, there is a slight degree of correlation between the level of GDP and the studied indicators. The paper econometrically assesses the relationships between the gross domestic product, foreign charges for the use of intellectual property and high-technology exports. The information base of the research comprises the World Bank data for 38 European states for 1992-2016. The results of the study generally confirm the suggested hypothesis. Developed countries show a positive correlation of the gross domestic product growth from these factors, and in terms of importance, intellectual property exports prevail over these of high-tech products. Within the countries of catching-up development the research registers ambiguous dependencies. The authors point out the complexity of interpretation of the indicator of the amount of charges for the use intellectual property arising from the implicit differentiation of income from domestic intellectual developments and developments used in assembly operations. The obtained results can be used to study the trends and trajectories of economic growth in highly developed, developing and temporarily lagging countries.
\end{abstract}

Keywords: economic growth; economic development; high-technology exports; economic inequality; intellectual property exports.

For citation: Buchinskaya O. N., Dyatel E. P. Influence of high-technology exports and foreign charges for the use of intellectual property on economic growth. Journal of New Economy, 2019, vol. 20, no. 2, pp. 114-126. DOI: 10.29141/2073-1019-2019-20-2-7

Received January 28, 2019.

\section{Introduction}

Conomic growth and competitive advantage in the global market are the key indicators of a Unational economy. The drivers of economic growth that affect the country's competitiveness and its economic security, in our opinion, comprise the following key factors:

- high level of manufacturing technologies;

- different proportion of value added in the production of traditional industrial "Malthusian" commodities and high-tech "Schumpeterian" products;

- mature system of intellectual property including the protection of new technologies with patents and licences; 
- development of large transnational companies with production process distributed across various countries when research and development is conducted in their headquarters, while assembly is carried out in the foreign branches.

As a result, the state of a country's economy is largely determined by its access to high technologies and intellectual property, as well as the ability to benefit from their use.

The objective of the study is to evaluate the influence of charges for the use of exported intellectual property and high value-added exports (in monetary terms) on the processes of economic growth in European countries.

The research implies fulfilling the following tasks: 1) to assess the cumulative impact of the target variables on the gross domestic product (GDP) of the entire group of countries to identify the general relationship between the factors of interest; 2) to assess the effect of the examined factors on the GDP to identify the dependence of the country's economic growth on the correlation between the measured indicators, and determine which of the factors has the prevailing effect on a particular country.

The authors applied econometric analysis as the main method of research including a fixedeffects model to evaluate the entire data set and the method of least squares for each individual country model. Gretl statistical package was used to assess the correlation between the GDP (in current US dollars), foreign charges for the use of intellectual property (as per the balance of payments, in current US dollars), and high-technology exports (in current US dollars) for 38 European countries in 1992-2016.

High-technology exports are products with high research and development (R \& D) intensity, such as in aerospace, computers, pharmaceuticals, scientific instruments, and electrical machinery.

Charges for the use of intellectual property (calculated according to the balance of payments) are payments and receipts between residents and nonresidents for the authorised use of proprietary rights (such as patents, trademarks, copyrights, industrial processes and designs including trade secrets, and franchises) and for the use, through licensing agreements, of produced originals or prototypes (such as copyrights on books and manuscripts, computer software, cinematographic works, and sound recordings) and related rights (such as for live performances and television, cable, or satellite broadcast $)^{1}$.

\section{Theoretical framework of high technology influence on economic growth}

Economic growth is considered to be one of the most important goals of any modern national economy. There are many approaches conceptualising the drivers of economic growth. In the 1980-s, an export-led growth (ELG) hypothesis was put forward.

Balassa [1978, p. 182], Heller, and Porter [1978, p. 192] argued that export growth is the one to influence the growth of gross domestic product. Later on, Giles and Williams [2000a; 2000b] came to a conclusion that high export volumes do not always correspond to economic growth.

An alternative approach to ELG suggests that the composition of exports affects the rate of economic growth and leads to a deeper economic differentiation among the countries of the world.

The theory of innovation by Schumpeter $[1934 ; 1939]$ is one of the first scientific attempts to study into the impact of high technology on economic growth. The expansion of innovative activity is considered to be a factor capable of increasing the national (gross) added value and stimulating high business activity. This concept has been further developed by Bazhal [2016,

\footnotetext{
${ }^{1}$ The World Bank Data Catalogue. Available at: https://datacatalog.worldbank.org/charges-use-intellectualproperty-receipts-bop-current-us-1
} 
p. 10] who referred to the so-called "Solow residual" as the central production factor. It expresses the multi-factor productivity which includes endogenous factors related to such phenomena as development of human capital, patent activity, R \& D funding, etc.

Attempts to study the dependence of economic growth on high technologies were made by Dosi, Pavitt, and Soete [1990], as well as Fagerberg [1995]. The findings of their research indicate that $\mathrm{R} \& \mathrm{D}$-oriented product groups (airplanes, cars, power engineering, and electronics) form an important competitive factor; sometimes (albeit not always) they also constitute a large proportion of military spending. When analysing high-tech firms operating in Europe, Cantwell and Janne [1999, p. 125] demonstrated that small and open economies usually specialise in individual niches since they have less opportunity to finance their own R \& D. Keller [2004, p. 775] suggested that in larger countries the growth of productivity relies on domestic industry to a lesser extent than in smaller ones. At the same time, Basu and Weil [1998] noted that technologies invented in developed countries may not be applicable to the poorer ones. In the same way, Machin, van Reenen [1998], and Acemoglu [2002] argued that the qualitative nature of modern technologies can be the main factor behind inequality.

According to Reinert [2006], inequality in economic growth is not caused by dependence on exports as such but is driven by the sale of the high value-added and highly innovative goods abroad. As a result, the countries that specialise in the export of high-tech goods while reserving the right to do R \& D and receive payments from licensing their technologies out, become leaders. Those that only produce simple goods lose additional revenue and their growth is significantly inferior to that of the more technologically advanced countries. Having examined a group of 84 countries in 1994-2003, Ferragina and Pastore [2007] suggested that high technologies had a positive and significant effect on the overall export performance and, therefore, on the GDP growth.

On the other hand, Srholec [2007] showed that the strong orientation of some countries (especially developing ones) towards electronics exports largely reflects the fact that production facilities are being allocated to these countries as a result of the development of transnational production networks, which affects the statistics on manufacturing.

In a study by Gani [2009], high-tech exports are recognised as a crucial factor behind economic growth basing on the data from 45 countries for 1996-2004. He found that high-technology export has a positive effect, and the correlation coefficient is generally statistically significant throughout the entire group of countries, despite being statistically insignificant for those in the potential leader category. In the same year, Falk [2009] found that high-tech exports of industrialised countries impact the GDP, but business R \& D intensity is more important than the share of high-tech exports in explaining economic growth. According to the findings reported by Bertchek et al. [Bertschek, Hogrefe, Rasel, 2015] profits and labour productivity of the companies exporting high-tech goods are significantly higher than those of the companies exporting low-tech products.

At the same time, there were studies of the impact of intellectual property rights and technology transfer on economic growth. For example, Yang and Maskus [2009] presented a model according to which welfare in recipient countries increases when enterprises in these countries are able to adopt high technology and use it effectively. On the contrary, welfare declines when companies in these countries cannot effectively take advantage of their access to high technology. Frietsch et al. [2014] note a strong correlation between patents and exports; in this regard. They argue that intellectual property in the form of patents can be a significant source of economic growth.

Analysis of 22 developing countries performed by Kılavuz and Topçu [2012] demonstrated that investment and high-tech production of export goods have a positive and significant effect 
on economic and demographic growth, while low-tech export industries have a positive but insignificant effect. Sara et al. [Sara, Jackson, Upchurch, 2012] identified a link between innovation and the country's level of high technology. Thus, the level of innovative activity can be evaluated by the volume of high-tech exports.

In a comparative analysis of South Korea and Turkey, Ustabaş and Ersin [2016, p. 53] noted that high-tech exports have a positive effect on the level of the GDP per capita in South Korea, but this conclusion is not applicable to Turkey, which can be explained by the low share of hightech goods in Turkey's total exports. In contrast, Yelkikalan et al. [Yelkikalan, Aydin, Kurt, 2017, p. 88], when analysing the high technology impact on economic growth in Turkey, proved that technological progress stimulates economic growth through financial stability. Besides, investment in the country's advanced technologies is an important factor in ensuring political and financial stability.

Usman [2017, p. 101] noted the significant positive impact of high-tech exports on economic growth, although in countries with the strong agricultural orientation of the economy and a small number of high-tech goods the effect of this variable is less important than that of the agricultural sector.

\section{Research results}

The first stage involved testing the panel model of dependence of the logarithm of GDP in current US dollars (1_GDPcurrentUS) on the logarithms of high-tech exports (1_Hightech ) and charges for the use of intellectual property (1_Charges) expressed in the same currency. The findings of the panel analysis with fixed effects of 705 observations from 38 countries are summarised in Table 1.

Table 1. Assessment of the combined effect of high-tech exports and charges for the use of intellectual property on GDP (dependent variable: 1_GDPcurrentUS)

Таблица 1. Оценка совместного влияния экспорта высокотехнологичной продукции и сборов за использование интеллектуальной собственности на ВВП (зависимая переменная: I_GDPcurrentUS)

\begin{tabular}{|l|c|c|c|c|c|}
\hline & Coefficient & Std. Error & t-ratio & p-value & Significance \\
\hline Y intercept & 13.9644 & 0.3609 & 38.6933 & $<0.0001$ & ${ }^{* *}$ \\
\hline 1_Charges & 0.211832 & 0.0163469 & 12.9585 & $<0.0001$ & ${ }^{* * *}$ \\
\hline 1_Hightech & 0.311933 & 0.0229906 & 13.5678 & $<0.0001$ & ${ }^{* * *}$ \\
\hline Mean dependent var & 24.96637 & \multicolumn{2}{l}{ S.D. dependent var } & 3.084359 \\
\hline Sum squared resid & 72.70104 & \multicolumn{2}{l}{ S.E. of regression } & 0.330643 \\
\hline LSDV R-squared & 0.989145 & \multicolumn{2}{l}{ Within R-squared } & 0.639985 \\
\hline LSDV F(39, 665) & 1553.742 & \multicolumn{2}{l|}{ P-value(F) } & 0.000000 \\
\hline Log-likelihood & -199.5273 & Akaike criterion & 479.0546 \\
\hline Schwarz criterion & 661.3825 & Hannan-Quinn & 549.5119 \\
\hline Rho & 0.762967 & Durbin-Watson & 0.446052 \\
\hline
\end{tabular}

Note. Compiled using the data from the World Bank Group. Available at: https://databank.worldbank. org/.

Table 1 employs the following indicators:

Y - the logarithm of GDP in current US dollars;

1_Charges - the logarithm of charges for the use of intellectual property, payments by BoP in current US dollars;

1_Hightech - the logarithm of high technology exports in current US dollars;

$* * *$ - the significance at $1 \%$ level. 
The analysis reveals the existence of the relationship between GDP and the studied variables. However, the countries of the observed region are developing very unevenly. Recently industrialized countries with a high level of income have been showing a tendency towards moving their assembly facilities to the regions with lower natural and human resources, while maintaining the head enterprises in highly developed countries to specialise in design, modification, and introduction of new products and models. Reshoring processes are currently not widespread and therefore cannot be considered in the study. In the early 1990-s, a number of countries experienced deindustrialisation and economic recession as a result of transition from the centralised management of the national economy to a socioeconomic market system. This predetermined their lag in design and manufacturing of their own high-tech products and turned them into an assembly base and a sales market for the high-tech goods from other countries.

As a result of globalisation processes and the activities of transnational companies, design and implementation processes that account for the major portion of the added value are performed in parent companies, while the stages of final assembly and mass production take place in the units located in other (poor) countries. Eremenko [2015, c. 548] identifies four types of integration systems: two clusters of high- and middle-tech donor countries and two clusters of technology recipient countries. This duality explains the high level of determination between GDP and high-tech exports in relation to countries with a low share of production sector and to the countries that experienced deindustrialisation during the transition from the socialist socioeconomic system to the market economy. At the same time, the countries with a high level of industrial development (Sweden, the United Kingdom) show a low coefficient of determination. In our opinion, charges for the use of intellectual property play an important role in economic growth of these countries.

To test this hypothesis, the ordinary least squares regression was performed in three cases: the combined effect of high-tech exports and intellectual property on GDP, as well as individual regressions intended to identify the effect of a singled-out variable.

It can be seen from Table 2 that four countries show no significant relationship between the examined variables. This applies to Albania, Malta, Serbia, and Montenegro. It should be noted that of these countries only Malta has a stable economy, while the rest were at the stage of deindustrialisation and simultaneously parties to the military conflict in the Balkans, which hindered development of their industry.

For Moldova, Greece, Croatia, Latvia, Finland, Estonia, the United Kingdom, Ireland, and Luxembourg the high-tech export variable was statistically insignificant, and for Poland the impact of this variable, though statistically significant, was inferior to the intellectual property contribution. In contrast, for Spain, Lithuania, Norway, France, the Czech Republic, and Switzerland the impact of intellectual property charges was statistically significant. In the case of Romania, Slovakia, and Ukraine this variable was significant yet seriously inferior to the effect of high technologies. It is important to mention the countries which showed negative effects in the combined model: Albania, Finland, Luxembourg, Montenegro, Poland, Russia, Serbia, and the United Kingdom - for the high-tech exports; Belgium, Bulgaria, the Czech Republic, Lithuania, the Slovak Republic, and Montenegro. The performance demonstrated by these countries is shown in Figs. 1 and 2.

Fig. 1 shows that the changes in high-tech exports from the economically developed countries (the United Kingdom, Finland) can be due to the consequences of the 2008 recession, which prompted reduction in costs and relocation of assembly facilities to other regions. Accordingly, some of the developing countries (such as Poland and Russia) demonstrated growth in these industries but their GDP is not so high and these industries are not dominant, therefore, the value of the variables turned out to be negative. 
Table 2. Combined effect of high-tech exports (htech) and charges for the use of intellectual property (intell) on GDP

Таблица 2. Совместное влияние на ВВП экспорта высоких технологий (htech) и отчислений за использование интеллектуальной собственности (intell)

\begin{tabular}{|c|c|c|c|c|c|}
\hline \multirow{2}{*}{ No. } & \multirow{2}{*}{ Country } & \multirow{2}{*}{ Constant } & \multicolumn{2}{|c|}{ Variable } & \multirow{2}{*}{$\mathrm{R}^{2}$} \\
\hline & & & htech & intell & \\
\hline & 1 & 2 & 3 & 4 & 5 \\
\hline 1 & Austria & $7.64 \mathrm{E}+10$ & 7.34 & 119.93 & 0.74 \\
\hline 2 & Albania & $7.65 \mathrm{E}+09$ & -25.7502 & 232.79 & 0.49 \\
\hline 3 & Belarus & $8.23 \mathrm{E}+09$ & 56.67 & 170.44 & 0.87 \\
\hline 4 & Belgium & $2.11 \mathrm{E}+11$ & 8.15 & -3.82415 & 0.69 \\
\hline 5 & Bulgaria & $1.42 \mathrm{E}+10$ & 51.32 & -68.6391 & 0.9 \\
\hline 6 & The United Kingdom & $2.40 \mathrm{E}+11$ & -1.37055 & 236.19 & 0.87 \\
\hline 7 & Hungary & $3.83 \mathrm{E}+10$ & 2.2 & 32.3 & 0.96 \\
\hline 8 & Germany & $1.19 \mathrm{E}+12$ & 7.85 & 111.18 & 0.88 \\
\hline 9 & Greece & $9.83 \mathrm{E}+10$ & 5.17 & 330.5 & 0.93 \\
\hline 10 & Denmark & $9.95 \mathrm{E}+10$ & 12.35 & 74.41 & 0.92 \\
\hline 11 & Ireland & $1.37 \mathrm{E}+11$ & 2.51 & 1.07 & 0.64 \\
\hline 12 & Iceland & $1.19 \mathrm{E}+10$ & 12.13 & 42.04 & 0.7 \\
\hline 13 & Spain & $2.90 \mathrm{E}+11$ & 54.29 & 38.46 & 0.97 \\
\hline 14 & Italy & $5.75 \mathrm{E}+11$ & 27.21 & 120.84 & 0.9 \\
\hline 15 & Latvia & $6.17 \mathrm{E}+09$ & 3.03 & 496.73 & 0.87 \\
\hline 16 & Lithuania & $1.22 \mathrm{E}+10$ & 21.34 & -49.6872 & 0.92 \\
\hline 17 & Luxembourg & $4.17 \mathrm{E}+10$ & -5.87883 & 6.52 & 0.56 \\
\hline 18 & Macedonia & $4.12 \mathrm{E}+09$ & 36.29 & 59.9 & 0.83 \\
\hline 19 & Malta & $3.54 \mathrm{E}+09$ & 1.37 & 4.2 & 0.47 \\
\hline 20 & Moldova & $1.51 \mathrm{E}+09$ & 12.35 & 278.15 & 0.95 \\
\hline 21 & The Netherlands & $2.60 \mathrm{E}+11$ & 4.57 & 7.28 & 0.92 \\
\hline 22 & Norway & $-2.12 \mathrm{E}+10$ & 105.59 & 12.67 & 0.95 \\
\hline 23 & Poland & $1.13 \mathrm{E}+11$ & -13.1262 & 217.67 & 0.94 \\
\hline 24 & \begin{tabular}{|l} 
Portugal \\
\end{tabular} & $5.29 \mathrm{E}+10$ & 26.51 & 187.51 & 0.84 \\
\hline 25 & The Russian Federation & $5.99 \mathrm{E}+11$ & -86.7073 & 295.58 & 0.97 \\
\hline 26 & Romania & $4.07 \mathrm{E}+10$ & 23.89 & 95.43 & 0.85 \\
\hline 27 & Serbia & $3.55 \mathrm{E}+10$ & -43.9124 & 107.09 & 0.33 \\
\hline 28 & Slovakia & $3.45 \mathrm{E}+10$ & 14.89 & -74.3167 & 0.84 \\
\hline 29 & Slovenia & $1.49 \mathrm{E}+10$ & 16.76 & 36.57 & 0.92 \\
\hline 30 & Ukraine & $-5.4 \mathrm{E}+09$ & 48.86 & 89.94 & 0.82 \\
\hline 31 & Finland & $9.46 \mathrm{E}+10$ & -0.993794 & 110.81 & 0.79 \\
\hline 32 & France & $6.86 \mathrm{E}+11$ & 18.44 & 9.58 & 0.86 \\
\hline 33 & Croatia & $1.60 \mathrm{E}+10$ & 5.62 & 144.84 & 0.86 \\
\hline 34 & Montenegro & $4.42 \mathrm{E}+09$ & -9.15388 & -15.3868 & 0.04 \\
\hline 35 & The Czech Republic & $5.09 \mathrm{E}+10$ & 9.32 & -26.4640 & 0.93 \\
\hline 36 & Switzerland & $9.89 \mathrm{E}+10$ & 10.73 & 1.54 & 0.99 \\
\hline 37 & Sweden & $9.85 \mathrm{E}+10$ & 10.57 & 85 & 0.79 \\
\hline 38 & Estonia & $4.58 \mathrm{E}+09$ & 0.09 & 331.04 & 0.89 \\
\hline
\end{tabular}

Note. Compiled using the data from the World Bank Group. Available at: https://databank.worldbank. org/ 


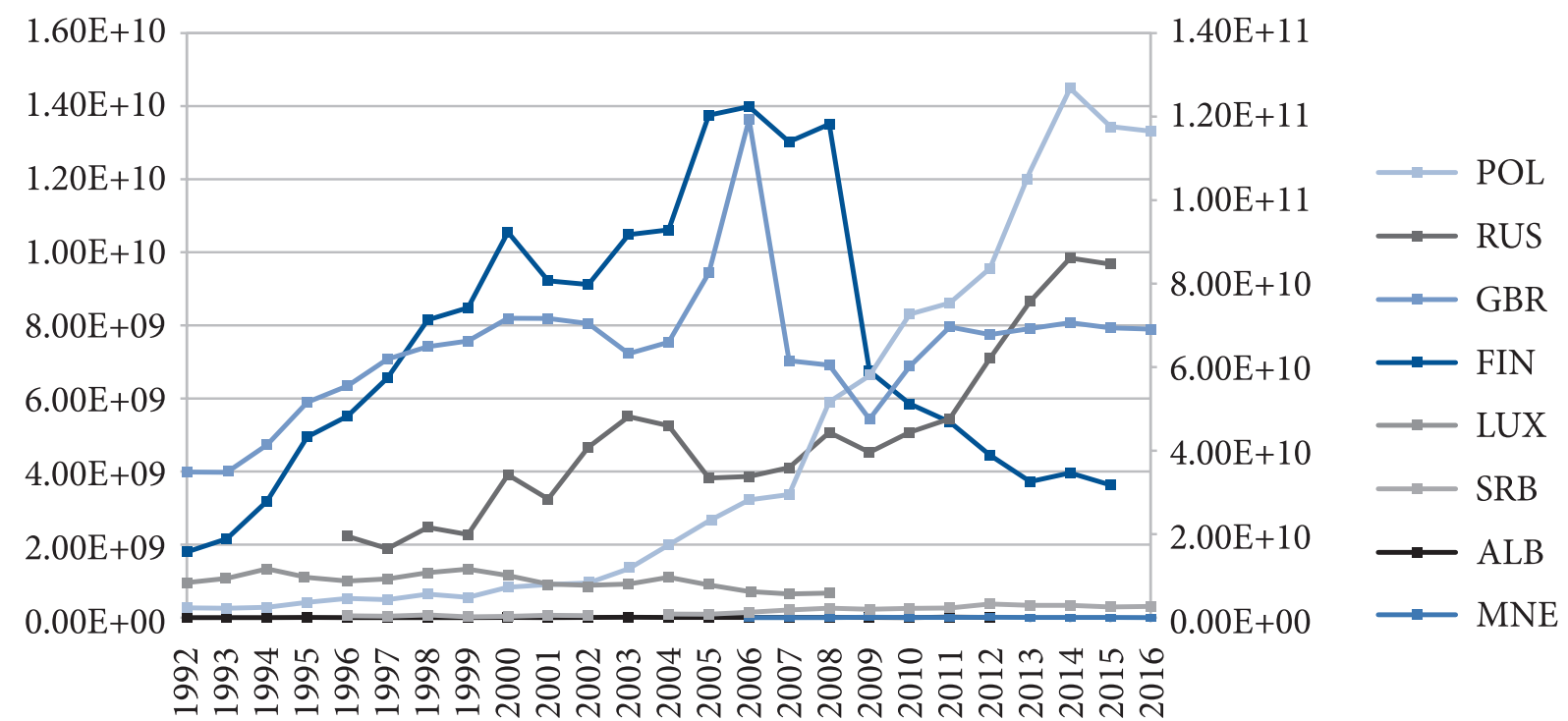

Fig. 1. High-technology exports in a number of countries in 1992-2016 (data for the UK is shown on the right auxiliary axis) ${ }^{1}$

Рис. 1. Динамика экспорта высоких технологий по ряду стран за 1992-2016 гг. (данные Великобритании приведены по правой вспомогательной оси)

Analysis of Fig. 2 shows an overall positive trend of the studied variable due to the general development of intellectual property rights and the share of intellectual property in the value of goods. However, the highest growth of this variable is experienced by the countries that, on the one hand, are not among the leaders in producing their own high-tech goods, and on the other hand serve as a staging area for the high-tech production of other countries (Belgium, the Czech Republic, and with a certain lag Slovakia). Thus, even growing charges for the use of intellectual property do not increase the GDP of these countries, since the increase is most likely generated by the use of patents and other items of intellectual property received from parent companies as a result of technology transfer to peripheral production.

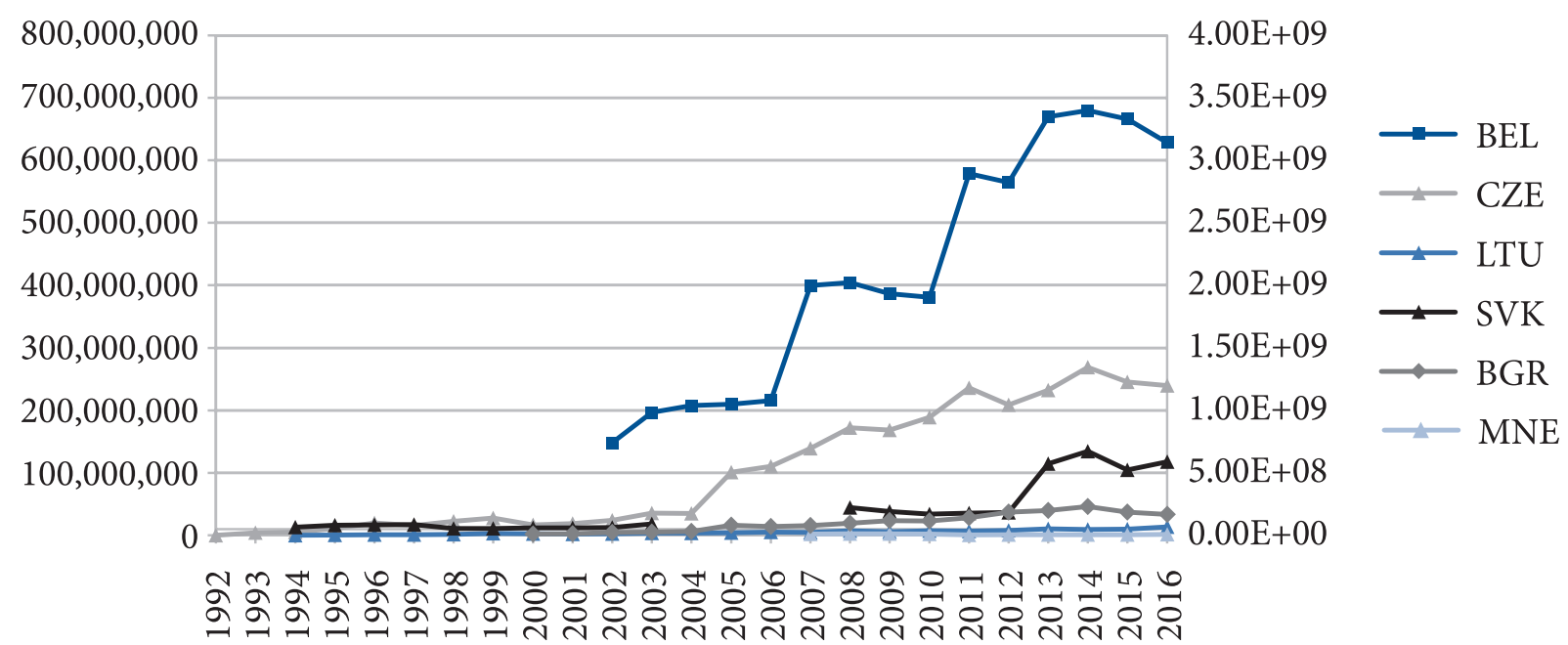

Fig. 2. Charges for the use of intellectual property in a number of countries in 1992-2016

(data for Belgium and the Czech Republic are shown on the right auxiliary axis) ${ }^{2}$

Рис. 2. Динамика сборов за интеллектуальную собственность по ряду стран за 1992-2016 гг. (данные Бельгии и Чехии приведены по правой вспомогательной оси)

\footnotetext{
${ }^{1}$ Note. Compiled using the data from the World Bank Group. Available at: https://databank.worldbank.org/ ${ }^{2}$ Ibid.
} 
From a regional perspective, high-tech exports are less significant in Western European countries, while intellectual property charges are less significant in Eastern Europe.

The impact of high-tech exports on Malta's and Moldova's GDP can be described as statistically insignificant. At the same time, such developed countries as the United Kingdom, Finland, Ireland, and Luxembourg de facto demonstrate no correlation between their GDP and hightech exports. Switzerland, Norway, Austria, Germany, France, Italy, and the Netherlands showed the strongest correlation among the world-leading countries.

High correlation is shown by Romania, Belarus, Slovenia, Hungary, Lithuania, and the Czech Republic, which received the assembly facilities relocated from the more developed countries. Russia demonstrates a relatively weak correlation between high-tech exports and GDP. This can be explained by the fact that the share of exports in the country's GDP is insignificant. Moreover, this share has been reducing since 2014 due to the international sanctions. However, when analysing the coefficients for the studied variables obtained by regression (see Table 2), the following trend can be noticed: the countries of Northern Europe and Western Europe feel a relatively small impact on the GDP with an increase in high-tech exports. The Southern European region, particularly, Eastern Europe, can ensure a significant rise in their wealth from domestic hightech production and exports if the tendency for their exports to grow continues. In this regard, Russia has ample opportunities as well, provided that it overcomes the foreign pressure.

Switzerland, the Netherlands, the United Kingdom, and France show the highest individual dependence of GDP on the charges for the use of intellectual property. The countries of Southern and Eastern Europe (Hungary, Russia, Spain, Moldova, Greece, and Poland) display a significant but weaker correlation. This is consistent with the findings reported by Branstetter et al. [Branstetter, Fisman, Fritz Foley, 2006]: an increase in royalties for the use of intellectual property is caused by the transfer of technologies from parent companies to their branches engaged in assembly production involving these patents and know-how.

Identifying the reasons behind the strong correlation is a topic of further research. In general, the value of the coefficient as compared to the variable charges for the use of intellectual property in most countries turned out to be significantly higher than the high-tech exports coefficient. This indicates a rising rate of development of this income category, especially in the countries which have not been focused on the need to improve the protection of intellectual property until recently.

It appears that, for the successful development of the Eastern European countries, it is necessary to stimulate, firstly, the production of their own high-tech goods and, secondly, the priority production of goods and services with a high proportion of intellectual property protected in a given country. This is crucial in the light of a rising trend towards the return of production facilities to the parent countries which leads to the reduction in employment and slowdown of economic growth in the countries with the assembly plants.

For the developing countries, it is important to note the relevance of legislative initiatives aimed at increasing the domestic production of high-tech goods. This is especially true for Russia, where a substantial share of nominally home-produced high-tech consumer goods originates from China with only brands legally registered in the Russian Federation. This situation holds Russia back in developing its own production of high-tech goods and allows no effective jobs to be created. Great emphasis is placed on the task of creating conditions where domestic science would receive income from its own designs and patents, establishing firms that would design the high-tech goods, particularly the ones engaged in fabless manufacturing. This would reduce the risk of "brain drain" and acquisition of domestic patents by foreign companies. An important condition, in our opinion, could be tax exemptions for the Russian entrepreneurs engaged in high-tech manufacturing. 


\section{Conclusion}

The research identified a steady correlation between the studied indicators in most countries. Only four countries out of 38 displayed a correlation of less than 0.5 on the Chaddock scale, while 14 countries showed an extremely high (over 0.9 ) correlation. In 15 countries hightechnology imports have stronger impact on the GDP growth than charges for use of intellectual property; in 19 countries charges for use of intellectual property have a greater impact than technology exports; and in four countries the results are considered statistically insignificant.

The high-tech exports are crucial for the countries with the most developed economic systems. The charges for the use of intellectual property prevail in both developed countries (the United Kingdom) and in countries with low business activity (Russia, Belarus, Greece, Albania). This phenomenon should predetermine the topic of further research. In the Russian Federation, a strong negative trend is observed in high-tech exports associated with the effects of political problems (sanctions) on the country's economy.

It is also necessary to improve the model of dependence of GDP on the examined variables by studying the trends of autocorrelation and the influence of interactions between individual countries.

The authors came to a conclusion that the success of most European economies is closely related to the high-tech exports, which is an important factor of economic growth. At the same time, foreign charges for the use of intellectual property are not so easily interpreted. They may indicate a post-industrial development of a country but this indicator gives no clear answer whether these payments are the income received by economic agents from their own designs or from those used in branches of the large transnational corporations.

\section{References}

Eremenko E. V. (2015). Structural features of Russia's participation in global and transnational technology transfer network. Materialy X Mezhdunarodnoy konferentsii "Rossiyskie regiony $v$ fokuse peremen" [Proc. 10th Int. Sci.-Prac. Conf. "Russian Regions in the Focus of Changes"]. Ekaterinburg: UrFU, pp. 546-551. Available at: https://conf-expert.urfu.ru/fileadmin/user_upload/site_15921/news/Web_ versija_sbornika_nojabrskoi_konferencii_2015.pdf. (in Russ.)

Acemoglu D. (2002). Technical change, inequality, and the labor market. Journal of Economic Literature, vol. 40, pp. 7-72.

Balassa B. (1978). Exports and economic growth: Further evidence. Journal of Development Economics, vol. 5, pp. 181-189.

Basu S., Weil D. (1998). Appropriate technology and growth. Quarterly Journal of Economics, vol. 113, pp. 1025-1054.

Bazhal J. (2016). The theory of economic development of J. A. Schumpeter: Key features. Available at: https://mpra.ub.uni-muenchen.de/69883.

Bertschek I., Hogrefe J., Rasel F. (2015). Trade and technology: New evidence on the productivity sorting of firms. Review of World Economics, vol. 151, pp. 53-72.

Branstetter L. G., Fisman R., Fritz Foley C. (2006). Do stronger intellectual property rights increase international technology transfer? Empirical evidence from U. S. firm-level panel data. Quarterly Journal of Economics, vol. 121, pp. 321-349.

Cantwell J., Janne O. (1999). Technological globalisation and innovative centres: The role of corporate technological leadership and locational hierarchy. Research Policy, vol. 28, pp. 119-144.

Dosi G., Pavitt H., Soete L. (1990). The economics of technical change and international trade. L.: Harvester Wheatsheaf.

Fagerberg J. (1995). Is there a large-country advantages of high-tech? Available at: https://core.ac.uk/ download/pdf/6484390.pdf.

Falk M. (2009). High-tech exports and economic growth in industrialized countries. Applied Economics Letters, vol.16, pp. 1025-1028. 
Ferragina A. M., Pastore F. (2007). High-tech export performance: Which role for diversification? Ninth Annual Conference ETSG. Athens: Athens University of Economics and Business, pp. 490-500.

Frietsch R., Neuhäusler P., Jung T., Van Looy B. (2014). Patent indicators for macroeconomic growth - the value of patents estimated by export volume. Technovation, vol. 34, pp. 546-558.

Gani A. (2009). Technological achievement, high technology exports and growth. Journal of Comparative International Management, vol. 12, pp. 31-47.

Giles J. A., Williams C. L. (2000a). Export-led growth: A survey of the empirical literature and some non-causality results. Part 1. Journal of International Trade and Economic Development, vol. 9, pp. 265-341.

Giles J. A., Williams C. L. (2000b). Export-led growth: A survey of the empirical literature and some non-causality results. Part 2. Journal of International Trade and Economic Development, vol. 9, pp. 445-470.

Heller P. S., Porter R. C. (1978). Exports and growth: An empirical re-investigation. Journal of Development Economics, vol. 5, pp. 191-193.

Keller W. (2004). International technology diffusion. Journal of Economic Literature, vol. 42, pp. $752-782$.

Kılavuz E., Topçu A. (2012). Export and economic growth in the case of the manufacturing industry: Panel data analysis of developing countries. International Journal of Economics and Financial Issues, vol. 2, pp. 201-215.

Machin S., Van Reenen J. (1998). Technology and changes in skill structure: Evidence from seven OECD countries. Quarterly Journal of Economics, vol. 113, pp. 1215-1244.

Reinert E. S. (2006). Evolutionary economics, classical development economics, and the history of economic policy: A plea for theorizing by inclusion. Available at: http://hum.ttu.ee/wp/paper1.pdf.

Sara T. S., Jackson F. H., Upchurch L. T. (2012). Role of innovation in hi-tech-exports of a nation. International Journal of Business and Management, vol. 7, pp. 85-93.

Schumpeter J. (1934). The theory of economic development. Mass.: Harvard University Press.

Schumpeter J. (1939). Business cycles I-II. New York: McGraw-Hill.

Srholec M. (2007). High-tech exports from developing countries: A symptom of technology spurts or statistical illusion? Review of World Economics, vol. 143, pp. 227-255.

Usman M. (2017). Impact of high-tech exports on economic growth: Empirical evidence from Pakistan. Journal on Innovation and Sustainability, vol. 8, pp. 91-105.

Ustabaş A., Ersin Ö. (2016). The effects of R\&D and high technology exports on economic growth: A comparative cointegration analysis for Turkey and South Korea. Proceedings of the international conference on Eurasian economies. Kaposvar, pp. 44-55.

Yang L., Maskus K. E. (2009). Intellectual property rights, technology transfer and exports in developing countries. Journal of Development Economics, vol. 90, pp. 231-236.

Yelkikalan N., Aydin E., Kurt U. (2017). Impact on economic growth of technological progress in the turkey economy: Empirical analysis on political and financial stability channel. International Business Research, vol. 10, pp. 80-90.

\section{Information about the authors}

Olga N. Buchinskaya, Cand. Sc. (Econ.), Associate Prof. of Economic Theory and Economic Policy Dept., Ural Federal University named after the first President of Russia Boris N. Yeltsin, 19 Mira St., Ekaterinburg, 620002, Russia

Phone: +7 (343) 261-45-18, e-mail: gto2000@list.ru

Evgeniy P. Dyatel, Dr. Sc. (Econ.), Prof. of Economic Theory and Economic Policy Dept., Ural Federal University named after the first President of Russia Boris N. Yeltsin, 19 Mira St., Ekaterinburg, 620002, Russia; Prof. of Political Economy Dept., Ural State University of Economics, 62/45 8 Marta/Narodnoy Voli St., Ekaterinburg, 620144, Russia

Phone: +7 (343) 261-45-18, e-mail: dyatel1942@mail.ru 
О. Н. Бучинская Уральский федеральный университет имени первого президента России Б. Н. Ельцина, г. Екатеринбург, Российская Федерация

Е. П. Дятел Уральский федеральный университет имени первого президента России Б. Н. Ельцина, Уральский государственный экономический университет,

г. Екатеринбург, Российская Федерация

\title{
Влияние на экономический рост высокотехнологичного экспорта и внешнеэкономических сборов за использование интеллектуальной собственности
}

\begin{abstract}
Аннотащия. Исследование направлено на выявление взаимосвязи высокотехнологичного экспорта и роста национальных экономик европейских стран. Методологически авторы опирались на концептуальные положения теории неравенства экономик Э. Райнерта и теории экспортоориентированного роста. Основная исследовательская гипотеза базируется на предположении о том, что возможность участия в экспорте высокотехнологичных товаров и объектов интеллектуальной собственности является существенной для достижения страной высокого экономического уровня. Соответственно, для стран, имеющих более низкий уровень экономического развития, характерна незначительная степень корреляции уровня ВВП и исследуемых показателей. Проведена эконометрическая оценка связей между валовым внутренним продуктом, внешнеэкономическими сборами за использование интеллектуальной собственности и экспортом высоких технологий. Информационная база исследования представлена данными Мирового банка за 1992-2016 гг. для 38 европейских государств. Результаты исследования в целом подтвердили выдвинутую гипотезу. Развитые страны демонстрируют положительную корреляцию роста валового внутреннего продукта от указанных факторов, причем по своей значимости экспорт интеллектуальной собственности превалирует над экспортом высокотехнологичной продукции. В странах догоняющего развития зафиксированы неоднозначные зависимости. Отмечена сложность интерпретации показателя величины сборов за использование интеллектуальной собственности из-за неявной дифференциации доходов от собственных интеллектуальных разработок и разработок, используемых на сборочных производствах. Полученные результаты могут быть применены при исследовании тенденций и траекторий экономического роста высокоразвитых, развивающихся и временно отстающих стран.
\end{abstract}

Ключевые слова: экономический рост; экономическое развитие; высокотехнологичный экспорт; экономическое неравенство; экспорт интеллектуальной собственности.

Для цитирования: Buchinskaya O. N., Dyatel E. P. Influence of high-technology exports and foreign charges for the use of intellectual property on economic growth // Journal of New Economy. 2019. T. 20, № 2. C. 114-126. DOI: 10.29141/2073-1019-2019-20-2-7 Дата поступления: 28 января 2019 г. 


\section{Источники}

Еременко Е. В. (2015). Конструктивные особенности участия России в глобальной и транснациональной сети трансфера технологий // Российские регионы в фокусе перемен: сборник докладов X Международной конференции. Екатеринбург: УрФУ. С. 546-551. URL: https:// conf-expert.urfu.ru/fileadmin/user_upload/site_15921/news/Web_versija_sbornika_nojabrskoi_ konferencii_2015.pdf.

Acemoglu D. (2002). Technical change, inequality, and the labor market. Journal of Economic Literature, vol. 40, pp. 7-72.

Balassa B. (1978). Exports and economic growth: Further evidence. Journal of Development Economics, vol. 5, pp. 181-189.

Basu S., Weil D. (1998). Appropriate technology and growth. Quarterly Journal of Economics, vol. 113, pp. 1025-1054.

Bazhal J. (2016). The theory of economic development of J. A. Schumpeter: Key features. Available at: https://mpra.ub.uni-muenchen.de/69883.

Bertschek I., Hogrefe J., Rasel F. (2015). Trade and technology: New evidence on the productivity sorting of firms. Review of World Economics, vol. 151, pp. 53-72.

Branstetter L. G., Fisman R., Fritz Foley C. (2006). Do stronger intellectual property rights increase international technology transfer? Empirical evidence from U. S. firm-level panel data. Quarterly Journal of Economics, vol. 121, pp. 321-349.

Cantwell J., Janne O. (1999). Technological globalisation and innovative centres: The role of corporate technological leadership and locational hierarchy. Research Policy, vol. 28, pp. 119-144.

Dosi G., Pavitt H., Soete L. (1990). The economics of technical change and international trade. L.: Harvester Wheatsheaf.

Fagerberg J. (1995). Is there a large-country advantages of high-tech? Available at: https://core.ac.uk/ download/pdf/6484390.pdf.

Falk M. (2009). High-tech exports and economic growth in industrialized countries. Applied Economics Letters, vol.16, pp. 1025-1028.

Ferragina A. M., Pastore F. (2007). High-tech export performance: Which role for diversification? Ninth Annual Conference ETSG. Athens: Athens University of Economics and Business, pp. 490-500.

Frietsch R., Neuhäusler P., Jung T., Van Looy B. (2014). Patent indicators for macroeconomic growth - the value of patents estimated by export volume. Technovation, vol. 34, pp. 546-558.

Gani A. (2009). Technological achievement, high technology exports and growth. Journal of Comparative International Management, vol. 12, pp. 31-47.

Giles J. A., Williams C. L. (2000a). Export-led growth: A survey of the empirical literature and some non-causality results. Part 1. Journal of International Trade and Economic Development, vol. 9, pp. 265-341.

Giles J. A., Williams C. L. (2000b). Export-led growth: A survey of the empirical literature and some non-causality results. Part 2. Journal of International Trade and Economic Development, vol. 9, pp. 445-470.

Heller P. S., Porter R. C. (1978). Exports and growth: An empirical re-investigation. Journal of Development Economics, vol. 5, pp. 191-193.

Keller W. (2004). International technology diffusion. Journal of Economic Literature, vol. 42, pp. 752-782.

Kılavuz E., Topçu A. (2012). Export and economic growth in the case of the manufacturing industry: Panel data analysis of developing countries. International Journal of Economics and Financial Issues, vol. 2, pp. 201-215.

Machin S., Van Reenen J. (1998). Technology and changes in skill structure: Evidence from seven OECD countries. Quarterly Journal of Economics, vol. 113, pp. 1215-1244.

Reinert E. S. (2006). Evolutionary economics, classical development economics, and the history of economic policy: A plea for theorizing by inclusion. Available at: http://hum.ttu.ee/wp/paper1.pdf.

Sara T. S., Jackson F. H., Upchurch L. T. (2012). Role of innovation in hi-tech-exports of a nation. International Journal of Business and Management, vol. 7, pp. 85-93. 
Schumpeter J. (1934). The theory of economic development. Mass.: Harvard University Press.

Schumpeter J. (1939). Business cycles I-II. New York: McGraw-Hill.

Srholec M. (2007). High-tech exports from developing countries: A symptom of technology spurts or statistical illusion? Review of World Economics, vol. 143, pp. 227-255.

Usman M. (2017). Impact of high-tech exports on economic growth: Empirical evidence from Pakistan. Journal on Innovation and Sustainability, vol. 8, pp. 91-105.

Ustabaş A., Ersin Ö. (2016). The effects of R\&D and high technology exports on economic growth: A comparative cointegration analysis for Turkey and South Korea. Proceedings of the international conference on Eurasian economies. Kaposvar, pp. 44-55.

Yang L., Maskus K. E. (2009). Intellectual property rights, technology transfer and exports in developing countries. Journal of Development Economics, vol. 90, pp. 231-236.

Yelkikalan N., Aydin E., Kurt U. (2017). Impact on economic growth of technological progress in the turkey economy: Empirical analysis on political and financial stability channel. International Business Research, vol. 10, pp. 80-90.

\section{Информация об авторах}

Бучинская Ольга Николаевна, кандидат экономических наук, доцент кафедры экономической теории и экономической политики Уральского федерального университета имени первого президента России Б. Н. Ельцина, 620002, РФ, г. Екатеринбург, ул. Мира,19

Контактный телефон: +7 (343) 261-45-18, e-mail: gto2000@list.ru

Дятел Евгений Петрович, доктор экономических наук, профессор кафедры экономической теории и экономической политики Уральского федерального университета имени первого президента России Б. Н. Ельцина, 620002, РФ, г. Екатеринбург, ул. Мира,19; профессор кафедры политической экономии Уральского государственного экономического университета, 620144, РФ, г. Екатеринбург, ул. 8 Марта/Народной Воли, 62/45

Контактный телефон: +7 (343) 261-45-18, e-mail: dyatel1942@mail.ru

(c) Бучинская О. Н., Дятел Е. П., 2019 